\title{
XPD Lys751Gln increases the risk of breast cancer
}

\author{
MANI SAMSON ${ }^{1}$, SHIRLEY SUNDER SINGH ${ }^{2}$, RANGANATHAN RAMA ${ }^{4}$, \\ VELUSWAMI SRIDEVI $^{3}$ and THANGARAJAN RAJKUMAR ${ }^{1}$
}

\author{
Departments of ${ }^{1}$ Molecular Oncology, ${ }^{2}$ Pathology, ${ }^{3}$ Surgical Oncology, and ${ }^{4}$ Division of Epidemiology \\ and Cancer Registry, Cancer Institute (WIA), Adyar, Chennai 600020, India
}

Received August 16, 2010; Accepted November 8, 2010

DOI: $10.3892 / \mathrm{ol} .2010 .220$

\begin{abstract}
Breast cancer incidence has been on the increase in south Indian women. Polymorphisms in DNA repair genes modify an individual's risk to cancer. XPD (Xeroderma pigmentosum D), a DNA helicase gene involved in nucleotide excision repair and transcription coupled repair, may affect an individual's DNA repair capacity, particularly that of bulky adducts. This case-control study (250 breast cancer cases and 500 healthy controls) aimed to investigate the role of the XPD Lys751Gln polymorphism as a risk factor in the development of breast cancer. Genotyping was performed using the Taq Man allelic discrimination assay. Immunohistochemistry was used to quantitate the level of polycyclic aromatic hydrocarbon (PAH) adducts in biopsy samples obtained from the breast cancer patients. Results showed that the XPD Gln/ $G l n$ genotype was significantly associated with an increased risk of breast cancer (OR, 1.75; 95\% CI 1.02-2.80), particularly in premenopausal female patients (OR, 2.6; 95\% CI 1.33-4.79). PAH adduct levels were significantly higher in the cases with breast cancer as compared to the normal breast tissue. This study reveals that XPD may play a role in increasing breast cancer risk particularly in premenopausal females.
\end{abstract}

\section{Introduction}

Breast cancer is the second most frequent cause of cancerrelated death among women (1). An increase in the incidence of breast cancer of almost 200\% since 1982 in south Indian women was noted in the Madras Metropolitan Tumor Registry (2). The age standardized rate was 30.1/100,000 in 2009 in the Madras Metropolitan area.

The DNA of an individual is regularly damaged by endogenous and exogenous carcinogens. Female individuals at high risk of breast cancer are more likely to achieve subop-

Correspondence to: Professor T. Rajkumar, Department of Molecular Oncology, Cancer Institute (WIA), Adyar, Chennai 600020, India

E-mail: drtrajkumar@gmail.com

Key words: breast cancer, XPD751/Gln, DNA adduct, polycyclic aromatic hydrocarbon, DNA repair timal DNA repair (3). The nucleotide excision repair (NER) pathway is responsible for repairing bulky adducts, and polymorphisms in genes involved in the NER pathway may play a key role in sporadic cancer. Genetic variation in NER genes modulates the level of DNA damage sustained in response to carcinogen exposure (4). XPD (ERCC2), involved in the NER pathway, is a potential low-penetrance cancer susceptibility gene. Various polymorphisms wre described in the XPD gene, including those at exons 10 Asp312Asn and 23 Lys751Gln (5). The Lys751Gln polymorphism, located in the C-terminal region, undergoes a major change in the conformation of the respective amino acid in a significant interaction domain of the protein (6).

Polyaromatic hydrocarbons (PAHs) are potent mammary carcinogens occurring in humans and experimental animals (7). Mane et al (8) and Calaf and Russo (9) reported that PAHs are metabolized in human breast epithelial tissue to form PAH-DNA adducts. Molecular epidemiologic studies have associated PAH exposure with the risk of breast cancer $(10,11)$. Detection of these PAH-DNA adducts in human tissues serves as a phenotypic marker for the biologic effects of both carcinogen exposure and host DNA repair capacity (12). The adduct levels depend on the levels of exposure that cause DNA adducts, as wll as on individual variations in response to such exposure, including cellular absorption, distribution, metabolic activation and detoxification, and DNA repair capacity (13).

A case control study was conducted to verify the role of the XPD Lys715Gln polymorphism as a risk factor in the development of breast cancer in south Indian women. using immunohistochemistry, the allelic frequencies of the XPD Lys $715 \mathrm{Gln}$ polymorphism and the possible interaction between the XPD genotype and PAH adduct levels in breast biopsies were investigated.

\section{Materials and methods}

Patients. The details of the case control study were previously published (14). Briefly, 250 breast cancer cases and 500 healthy controls were matched on a five-year age category at a ratio of 1:2. The inclusion criteria for the healthy controls were: no prior diagnosis of benign breast diseases; no history of hysterectomy, mastectomy or oophorectomy; no relatives with breast, ovarian, endometrial or prostate cancer; no physical or mental disability which would preclude their participation 
A

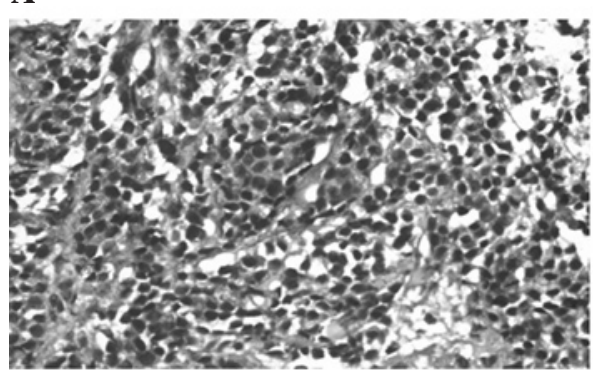

B

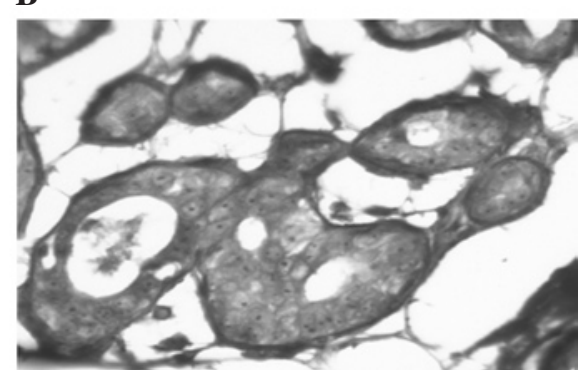

Figure 1. Immunohistochemistry was used to quantitate the PAH adducts using the 5D11 antibody. (A) Breast cancer sample positive for PAH-DNA adducts. (B) Normal breast tissue stained for PAH-DNA adducts.

Table I. Association of XPD Lys751Gln and breast cancer risk using univariate and multivariate conditional logistic regression analysis.

\begin{tabular}{|c|c|c|c|c|c|c|}
\hline \multirow[b]{2}{*}{$X P D$} & \multirow[b]{2}{*}{ Cases } & \multirow[b]{2}{*}{ Controls } & \multicolumn{2}{|c|}{ Univariate } & \multicolumn{2}{|c|}{ Multivariate } \\
\hline & & & OR & $95 \%$ CI & OR & $95 \%$ CI \\
\hline Lys/Lys & 107 & 235 & $1.00^{\mathrm{a}}$ & & $1.00^{\mathrm{a}}$ & \\
\hline$G \ln / G \ln$ & 41 & 51 & 1.75 & $(1.02-2.80)^{\mathrm{b}}$ & 1.75 & $(1.05-2.91)^{\circ}$ \\
\hline Lys/Gln & 102 & 214 & 1.05 & $(0.76-1.45)$ & 1.06 & $(0.75-1.51)$ \\
\hline
\end{tabular}

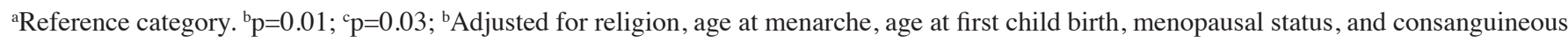
marriage. OR, odds ratio; CI, confidence interval.

in the study. Inclusion criteria for the cases were: histological confirmation of breast cancer and no previous cancer treatment. Informed consent was mandatory for both groups.

Genotyping. XPD Lys751Gln genotyping analysis was performed using the Taq Man allelic discrimination assay (Applied Biosystems, Foster City, CA, USA). Primers and probe mix were obtained directly from Applied Biosystems, Assays-on-Demand ${ }^{\mathrm{TM}}$.

Controls for the analysis of PAH adducts using immunohistochemistry (IHC). Formalin-fixed paraffin-embedded archival samples of a lung tumor from a smoker (more than 30 cigarettes per day) was used as the positive control for the IHC study. The samples showed $100 \%$ positivity for the $\mathrm{PAH}$ adduct. Normal breast tissue samples $(\mathrm{n}=20)$ included in the study were collected from patients diagnosed with breast disease other than a malignancy, such as fibroadenoma or fibroadenosis. Only normal breast tissue (control) extracted at a distance from the pathology was included for evaluation.

Quantitation of PAH adducts was studied in 65 breast cancer biopsy samples using IHC, as described by Yarborough et al (15).

Scoring of the slides. Tumors were scored for the percentage of immunoreactive tumor cells and the intensity of nuclear immunoreactivity. The intensity of staining was graded as: 0 , no staining; $1+$, weak immunoreactivity; $2+$, moderate immunoreactivity; and 3+, strong immunoreactivity. The number of tumor cells stained was classified as: 0 , no stained cells; $1+,<25 \%$ stained cells; $2+, 25-50 \%$ stained cells; $3+, 50-75 \%$ stained cells; and $4+,>75 \%$ stained cells. The sums of the scores were obtained, and a cut-off of $\leq 3$ was used to classify the samples as negative or positive.

\section{Results}

The frequency of the XPD Gln allele in the control population was 0.316 . The proportion of the XPD Gln allele containing the genotypes was significantly different between the cases (16.4\%) and controls (10.2\%). The variant $G \ln$ allele was associated with an increased risk of breast cancer in the univariate $(\mathrm{p}=0.01)$ and multivariate analysis $(\mathrm{p}=0.03)$ (Table I). This association was mainly confined to premenopausal women (univariate-adjusted OR, 2.6; 95\% CI 1.33-4.79, $\mathrm{p}=0.003$; and multivariate-adjusted OR, 2.73; 95\% CI 1.43-5.20, ( $\mathrm{p}=0.002$ ) (Table IIA and B).

Scoring for IHC was based on the staining intensity and the number of positive cells. Samples with a score $>3$ were more likely to be from a tumor than from normal breast tissue $(\mathrm{p}=0.005)$ (Table III).

Since $X P D$ is involved in the NER pathway, and PAH is cleared by the NER pathway, we studied the genotypephenotype correlation of PAH adducts and $X P D$ genotypes. The normal breast samples (control) analyzed using IHC were genotyped for XPD Lys751Gln polymorphisms and correlated with the adduct levels in the breast samples. No statistically significant association between $X P D$ genotypes and the PAH adduct levels was noted (Table IVA and B). However, the 7 samples with a variant $G l n$ allele and an IHC score of $>3$ were tumor cases. 
Table II. Association between the XPD polymorphisms and breast cancer cases.

A, Premenopausal women.

\begin{tabular}{|c|c|c|c|c|c|c|}
\hline \multirow[b]{2}{*}{$X P D$} & \multicolumn{2}{|c|}{ Premenopausal } & \multicolumn{2}{|c|}{ Univariate } & \multicolumn{2}{|c|}{ Multivariate } \\
\hline & Case & Control & OR & $95 \% \mathrm{CI}$ & OR & $95 \% \mathrm{CI}$ \\
\hline Lys/Lys & 45 & 138 & $1.00^{\mathrm{a}}$ & & $1.00^{\mathrm{a}}$ & \\
\hline$G \ln / G \ln$ & 25 & 30 & 2.60 & $(1.33-4.79)^{\mathrm{b}}$ & 2.73 & $(1.43-5.20)^{\mathrm{c}}$ \\
\hline Lys/Gln & 45 & 135 & 1.02 & $(0.63-1.65)$ & 0.94 & $(0.57-1.55)$ \\
\hline
\end{tabular}

B, Postmenopausal women.

\begin{tabular}{|c|c|c|c|c|c|c|}
\hline \multirow[b]{2}{*}{$X P D$} & \multicolumn{2}{|c|}{ Postmenopausal } & \multicolumn{2}{|c|}{ Univariate } & \multicolumn{2}{|c|}{ Multivariate } \\
\hline & Case & Control & OR & $95 \% \mathrm{CI}$ & OR & $95 \% \mathrm{CI}$ \\
\hline Lys/Lys & 61 & 97 & $1.00^{\mathrm{a}}$ & & $1.00^{\mathrm{a}}$ & \\
\hline$G \ln / G \ln$ & 16 & 21 & 1.21 & $(0.69-2.50)$ & 1.38 & $(0.64-2.98)$ \\
\hline Lys/Gln & 57 & 79 & 1.15 & $(0.72-1.83)$ & 1.25 & $(0.76-2.05)$ \\
\hline
\end{tabular}

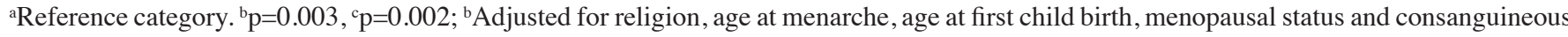
marriage. $\mathrm{OR}$, odds ratio; $\mathrm{CI}$, confidence interval.

Table III. Association between PAH adduct score and breast cancer risk.

\begin{tabular}{lccll}
\hline PAH score & Cases & $\begin{array}{c}\text { Normal tissue } \\
\text { (control) }\end{array}$ & OR & $95 \%$ CI \\
\hline$\leq 3$ & 24 & 15 & $1.00^{\mathrm{a}}$ & \\
$>3$ & 41 & 5 & 5.12 & $(1.65-15.8)$ \\
\hline
\end{tabular}

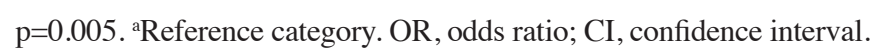

\section{Discussion}

The Lys751Gln polymorphism plays a significant role in the $X P D$ gene due to a major change in the conformation of the respective amino acid in a significant interaction domain of the protein (16). Lunn et al (17) studied the functional significance of XPD polymorphisms with respect to chromosome aberrations. These authors determined that individuals with the Lys/Lys genotype had a higher number of chromatid aberrations and sub-optimal repair of X-ray-induced DNA damage (OR, 7.2; 95\% CI, 1.01-87.7). A significant overall association was noted with regards to breast cancer risk for the carriers of the XPD Gln variant allele, and this risk was greater in premenopausal females.

In the present study, only the peripheral blood samples were collected from the controls for the case control study. No comparison was made between the adduct levels in the tumors obtained from the breast cancer patients and the levels in the normal breast tissue obtained from the controls. We therefore obtained archival samples of 'normal' breast tissue
Table IV.Association of XPD genotypes stratified by PAH-DNA adducts.

A, Three or less adducts.

\begin{tabular}{lcccc}
\hline$X P D$ & Cases & Controls & OR & $95 \%$ CI \\
\hline Lys $/$ Lys & 8 & 6 & $1.00^{\mathrm{a}}$ & - \\
Gln $/$ Gln & 4 & 4 & 0.75 & $(0.13-4.2)$ \\
Lys/Gln & 12 & 5 & 1.80 & $(0.40-7.9)$ \\
\hline
\end{tabular}

B, More than three adducts.

\begin{tabular}{lcclc}
\hline$X P D$ & Cases & Controls & OR & $95 \%$ CI \\
\hline Lys $/$ Lys & 15 & 3 & $1.00^{\mathrm{a}}$ & - \\
Gln $/$ Gln & 7 & 0 & 0 & 0 \\
Lys $/$ Gln & 19 & 2 & 1.90 & $(0.28-12.8)$ \\
\hline
\end{tabular}

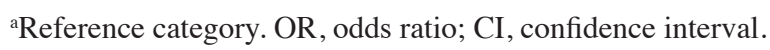

from patients who had undergone breast surgery for nonmalignant breast conditions which were included as 'normal breast tissue controls' for IHC. Although the breast tissue was morphologically normal, it was obtained from patients who had pathology in the breast (fibroadenoma and fibroadenosis). Genotyping was performed from the DNA extracted from the normal tissues.

No statistically significant association was found between the genotype and PAH adduct levels in the breast tissue samples. Terry et al (18) reported a $20 \%$ increased risk for 
breast cancer associated with the variant $G l n$ allele and higher levels of PAH adducts, with the risk being more pronounced among smokers. Similarly, Tang et al (19) observed higher DNA adduct levels among breast cancer patients who were $G \ln / G \ln$ homozygote carriers $(\mathrm{p}<0.01)$. Findings of various case-control studies showed that XPD 751 polymorphism carriers had a significantly or borderline increased risk of smoking-related cancers (20-22). A recent study in an Indian population noted that the $G l n$ allele increased both familial and sporadic breast cancer susceptibility (23). In their subgroup analysis, the study showed that the risk was reduced among familial breast cancer patients compared to sporadic breast cancer patients (OR, 0.61; 95\% CI 0.39-0.94; $\mathrm{p}=0.024)$. Brewster et al (24) observed no significant association between XPD Lys/Gln polymorphisms and family history of breast cancer. In their haplotype analysis, Justenhoven et al (25) showed that carriers of XPD Asp (312)/Gln (751) had an increased risk of breast cancer. However, other studies found no association between breast cancer and XPD Lys $751 G l n$ genotypes (26-30).

In our study population, a significant association was found between XPD Lys751Gln polymorphisms and breast cancer and, to some extent, with PAH adducts. No correlation was noted between PAH-DNA adduct levels and genes involved in DNA repair pathways, particularly the NER pathway, such as $X P D$, due to the small number of samples studied. In contrast to our results, Terry et al (18) reported that the polymorphism in XPD codon 751 was associated with a significantly increased breast cancer risk from PAH-DNA adducts and exposure to cigarette smoking. An increased risk of breast cancer among smokers may be due to carcinogens contained in tobacco smoke such as PAHs, aromatic amines and nitrosamines. In our study population, no case or control had a smoking habit. Therefore, we speculate that the source of PAHs was from the diet and environment.

Our findings suggest that XPD 751 polymorphisms play a role in the predisposition to breast cancer risk. We also conclude that, in premenopausal women, a constant exposure of steroid hormones and other environmental carcinogens to breast cells occurs. This exposure can initiate tumorigenesis by causing DNA damage. Any defects or alteration in the DNA repair genes may therefore affect repair mechanisms, thereby increasing an individual's risk for breast cancer. However, we did not find any statistically significant association between the PAH adduct levels, determined semi-quantitatively using IHC, and XPD 751 polymorphisms, presumably due to the small number of samples studied.

\section{Acknowledgements}

We thank Dr Regina Santella (Columbia University) for providing us with the antibody for the DNA adduct study, the Chennai Willingdon Corporate Foundation for funding the study and the Indian Council for Medical Research (ICMR) for providing the senior research fellowship. We also thank the patients and the subjects who participated as controls.

\section{References}

1. Jemal A, Siegel R, Ward E, Murray T, Xu J and Thun MJ: Cancer statistics. CA Cancer J Clin 57: 43-66, 2007.
2. Shanta V, Swaminathan R and Kavitha M: Cancer incidence and mortality in Chennai, India, year 2002. Madras Metropolitan Tumor Registry, National Cancer Registry Program, Cancer Institute (WIA), Chennai, 2005.

3. Helzlsouer KJ, Harris EL, Parshad R, Perry HR, Price FM and Sanford KK: DNA repair proficiency: potential susceptibility factor for breast cancer. J Natl Cancer Inst 88: 754-755, 2005.

4. Qiao Y, Spitz MR, Guo Z, Hadeyati M, Grossman L, Kraemer KH and Wei Q: Rapid assessment of repair of ultraviolet DNA damage with a modified host-cell reactivation assay using a luciferase reporter gene and correlation with polymorphisms of DNA repair genes in normal human lymphocytes. Mutat Res 509: 165-174, 2002.

5. Shen MR, Jones IM and Mohrenweiser H: Nonconservative amino acid substitution variants exist at polymorphic frequency in DNA repair genes in healthy humans. Cancer Res 58: 604-608, 1998.

6. Lehmann AR: XPD structure reveals its secrets. DNA Repair 7: 1912-1915, 2008.

7. El-Bayoumy K, Chae YH, Upadhyaya P, Meschter C, Cohen LA and Reddy BS: Inhibition of 7,12-dimethylbenz(a)anthraceneinduced tumors and DNA adduct formation in the mammary glands of female Sprague-Dawley rats by the synthetic organoselenium compound, 1,4-phenylenebis(methylene)selenocyanate. Cancer Res 52: 2402-2407, 1992.

8. Mane SS, Purnell DM and Hsu IC: Genotoxic effects of five polycyclic aromatic hydrocarbons in human and rat mammary epithelial cells. Environ Mol Mutagen 15: 78-82, 1990.

9. Calaf $\mathrm{G}$ and Russo J: Transformation of human breast epithelial cells by chemical carcinogens. Carcinogenesis 14: 483-492, 1993.

10. Rundle A, Tang D, Hibshoosh H, et al: The relationship between genetic damage from polycyclic aromatic hydrocarbons in breast tissue and breast cancer. Carcinogenesis 21: 1281-1289, 2000.

11. Li D, Zhang W, Sahin AA and Hittelman WN: DNA adducts in normal tissue adjacent to breast cancer: a review. Cancer Detect Prevent 23: 454-462, 1999.

12. Kyrtopoulos SA: Biomarkers in environmental carcinogenesis research: striving for a new momentum. Toxicol Lett 15: 3-15, 2006.

13. Binkova B, Chvatalova I, Lnenickova Z, Milcova A, Tulupova E, Farmer PB and Sram RJ: PAH-DNA adducts in environmentally exposed population in relation to metabolic and DNA repair gene polymorphisms. Mutat Res 620: 49-61, 2007.

14. Samson M, Swaminathan R, Rama R, Sridevi V, Nirmala NK and Rajkumar T: Role of GSTM1 (null/present), GSTP1 (Ile105Val) and P53 (Arg72Pro) genetic polymorphisms and the risk of breast cancer - a case control study from south India. Asian Pac J Cancer Prev 8: 253-257, 2007.

15. Yarborough A, Zhang YJ, Hsu TM and Santella RM: Immunoperoxidase detection of 8-hydroxydeoxyguanosine in aflatoxin B1-treated rat liver and human oral mucosal cells. Cancer Res 56: 683-688, 1996.

16. Benhamou S and Sarasin A: ERCC2/XPD gene polymorphisms and cancer risk. Mutagenesis 17: 463-469, 2002.

17. Lunn RM, Helzlsouer KJ, Parshad R, Umbach DM, Harris EL, Sanford KK and Bell DA: XPD polymorphisms: effects on DNA repair proficiency. Carcinogenesis 21: 551-555, 2000.

18. Terry MB, Gammon MD, Zhang FF, et al: Polymorphism in the DNA repair gene XPD, polycyclic aromatic hydrocarbon-DNA adducts, cigarette smoking, and breast cancer risk. Cancer Epidemiol Biomarkers Prev 13: 2053-2058, 2004.

19. Tang D, Cho S, Rundle A, et al: Polymorphisms in the DNA repair enzyme XPD are associated with increased levels of PAH-DNA adducts in a case-control study of breast cancer. Breast Cancer Res Treat 75: 159-166, 2002.

20. Hou SM, Fält S, Angelini S, Yang K, Nyberg F, Lambert B and Hemminki K: The XPD variant alleles are associated with increased aromatic DNA adduct level and lung cancer risk. Carcinogenesis 23: 599-603, 2002

21. Sturgis EM, Zheng R, Li L, et al: XPD/ERCC2 polymorphisms and risk of head and neck cancer: a case-control analysis. Carcinogenesis 21: 2219-2223, 2000.

22. Xing D, Tan W, Wei Q and Lin D: Polymorphisms of the DNA repair gene XPD and risk of lung cancer in a Chinese population. Lung Cancer 38: 123-129, 2002.

23. Syamala VS, Syamala V, Sreedharan H, Raveendran PB, Kuttan R and Ankathil R: Contribution of XPD (Lys751Gln) and XRCC1 (Arg399Gln) polymorphisms in familial and sporadic breast cancer predisposition and survival: an Indian report. Pathol Oncol Res 15: 389-397, 2009. 
24. Brewster AM, Jorgensen TJ, Ruczinski I, et al: Polymorphisms of the DNA repair genes XPD (Lys751Gln) and XRCC1 (Arg399Gln and Arg194Trp): relationship to breast cancer risk and familial predisposition to breast cancer. Breast Cancer Res Treat 95: 73-80, 2006

25. Justenhoven C, Hamann U, Pesch B, et al: ERCC2 genotypes and a corresponding haplotype are linked with breast cancer risk in a German population. Cancer Epidemiol Biomarkers Prev 13: 2059-2064, 2004.

26. Shore RE, Zeleniuch-Jacquotte A, Currie D, et al: Polymorphisms in XPC and ERCC2 genes, smoking and breast cancer risk. Int J Cancer 122: 2101-2105, 2008.

27. Kipikasová L, Wolaschka T, Bohus P, et al: Polymorphisms of the XRCC1 and XPD genes and breast cancer risk: a casecontrol study. Pathol Oncol Res 14: 131-135, 2008.
28. Romanowicz-Makowska H, Sobczuk A, Smolarz B, Fiks T and Kulig A: XPD Lys751Gln polymorphism analysis in women with sporadic breast cancer. Pol J Pathol 58: 245-249, 2007.

29. Dufloth RM, Costa S, Schmitt F and Zeferino LC: DNA repair gene polymorphisms and susceptibility to familial breast cancer in a group of patients from Campinas, Brazil. Genet Mol Res 4: 771-782, 2005.

30. Zhang L, Zhang Z and Yan W: Single nucleotide polymorphisms for DNA repair genes in breast cancer patients. Clin Chim Acta 359: 150-155, 2005. 